\title{
THE ROLE OF HALTICA SP. (COLEOPTERA: HALTICIDAE) AS BIOLOGICAL CONTROL AGENT OF POLYGONUM CHINENSE
}

\author{
KASNO \\ Faculty of Forestry Bogor Agricultural University, \\ Bogor, Indonesia \\ S. TJITROSEMTOAnd SUNJAY A \\ Tropical Agricultural Pest Biology Programme \\ SEAMEO BIOTROP, Bogor, Indonesia
}

\begin{abstract}
The role of Haltica sp. (Coleoptera: Halticidae) with emphasis on host specificity and damage potential in controlling Polygonum chinense was evaluated under laboratory condition.

Starvation test of the weevil on 33 weeds and 14 crop plant species indicated that only 6 weed species were attacked: Polygonum chinense, P. nepalense, P. barbatum, P. longisetum, Ludwigia octovalvis and $L$. parennis with $P$. chinense as the most preferred host plant.

Preliminary damage potential test indicated that a population of $0,1,2$ and 3 pairs of adult weevil reduced the percentage of fresh weight increment of $P$. chinense by $0 ; 46.2 ; 74.7$ and $75.5 \%$ respectively. Field observations indicated that the larvae as well as adult weevils are potential biological control agents of $P$. chinense. Further studies are, however, on the host-range of this weevil.
\end{abstract}

\section{INTRODUCTION}

Polygonum chinense $\mathrm{L}$. is one of the weeds growing amongst tea plantations in West Java but it has never been reported as a serious problem in the area. Locally it is known as "titiwuan" (Backer \& Slooten 1924) and in Thailand it is called "phayaadong" (Harada et al. 1987). It was reported to be distributed also from India eastward to Japan and it grows mostly on highland or open forest, coffee and tea plantations (Harada et al. 1987).

Although West Java is classified as a populated province, the utilization of labour to control weeds manually in large tea plantations is considered costly. Chemical control with herbicides is considered cheaper and more practical. On the other hand there is a strong demand to save the environment from any pollutant for better living. Therefore, it is necessary to develop other control methods in line with minimizing the side effects of herbicides and lowering the cost.

In the tea producing areas of West Java, there are many kinds of insects associated with $P$. chinense. Haltica sp. (Coleoptera: Halticidae) seems to be one of the most common and it causes considerable damage to the weed. A study on the potential role of the insect as biological control agent is needed. 


\section{MATERIALS AND METHODS}

Haltica sp. was collected from a tea plantation of PTP XII, Gunung Mas located about $30 \mathrm{~km}$ on the way from Bogor to Bandung. They were brought to BIOTROP Laboratory at Bogor for rearing and further observations on its life cycle, host specificity and damage potential. Some behavioural aspects of Haltica sp. were casually observed in the field.

The insects were reared in petri dishes and fed with fresh cut leaves of Polygonum chinense. The room temperature and relative humidity of the laboratory varied from $24-31{ }^{\circ} \mathrm{C}$ and $48-82 \%$ respectively.

Starvation test of newly hatched larvae and newly emerged weevil of Haltica sp. was done against 14 species of crop plants and 33 species of weeds (Appendix 1). Five heads of larvae and adult weevils in separate petri dishes were reared with a single fresh cut leaf of test plants. Replacement of fresh cut leaves of the test plants was done every day during the test. $P$. chinense was used as the control. The response parameter of the insect on the test plants was mainly the presence of feeding scars. Observation was done every 24 hours till most of the test insects died. When the test insects produced feeding scars, the test was continued till the sixth day to make sure that they can survive by consuming the cut leaves of the test plants. The positive test plants were tested further for food preference.

Preferential test using larvae of the insect was carried out against six species of weeds namely Polygonum chinense, P. longisetum, P. barbatum, P. nepalense, Ludwigia octovalvis and $L$. parennis. Six heads of Haltica larvae were released in petri dish containing six arranged pieces of the weed species. The inner space of each petri dish was equally divided into six radial sectors (Figure 1) and each piece of fresh cut leaves of test plants was put into each sector. Six heads of test weevil were released at the center of the petri dish to allow them to select freely the test leaves. The response parameter of the preferential test was the level of feeding scars on each test leaf.

Preliminary damage potential test of the weevils against $P$. chinense was carried out by releasing various numbers of adult weevils on 20 day-old plants. The average fresh weight of newly cut $P$. chinense before being transplanted into plastic pots was $14.30 \pm 2.27$ gram and the average leaf number was $11.85 \pm 1.59$ pieces. The pots were $15 \mathrm{~cm}$ in height, $10 \mathrm{~cm}$ and $15 \mathrm{~cm}$ in bottom and upper diameters, respectively. The pots were fully filled with light soil. The potted plants were allowed to grow for 20 days. Watering was done daily with tap water. To avoid attack of any insect, the potted plants were covered singly with screen cage. Various numbers of weevils e.g. 0, 1, 2 and 3 pairs were released on a single pot plant and kept for ten days. The test was run following Complete Randomized Design with 


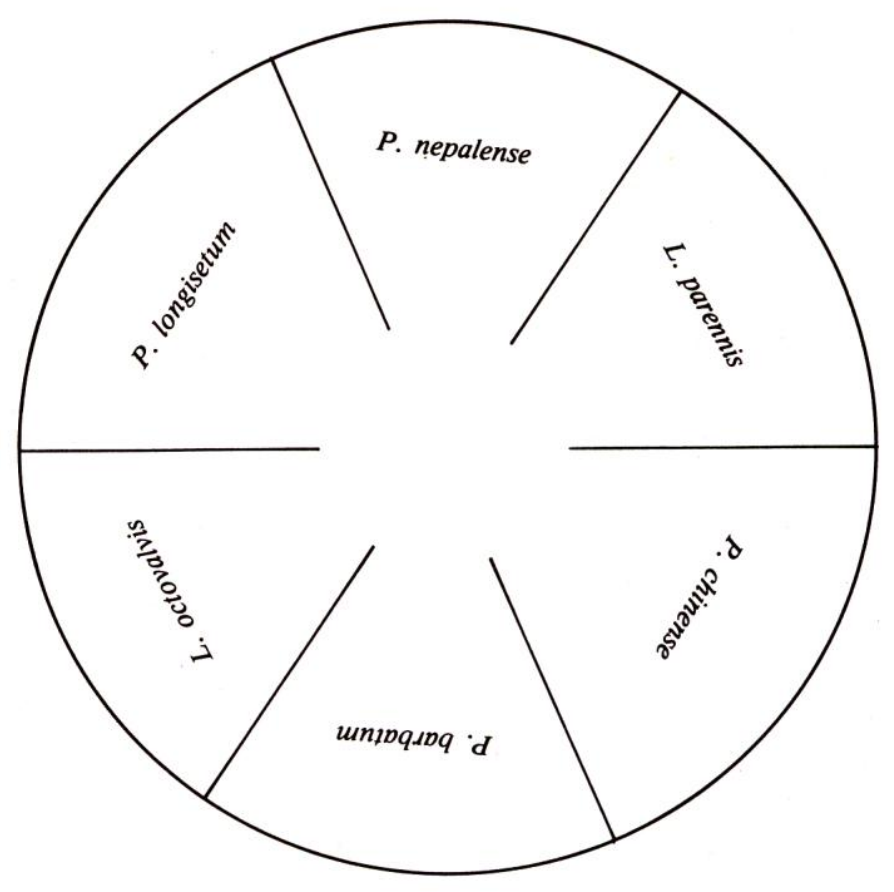

Figure 1. Six radial sectors of the petri dish used for preferential test.

5 (five) replications. The response parameter of the test was mainly based on the percentage of reduction of fresh weight compared with the control at the end of the test.

\section{RESULTS AND DISCUSSION}

Under laboratory conditions of $24-31{ }^{\circ} \mathrm{C}$ temperature and $48-82 \%$ relative humidity, respectively, the life cycle of the insect varied from 26 to 28 days. The incubation, larval and pupal periods were 5-6, 13-15 and 7 days, respectively. During the larval period, it molted three times, i.e. it had four larval instars. Other biological data such as adult longevity and egg production of an adult female have not been precisely observed. However, it seemed that the adult longevity was more than a month and egg production of a female was more than a hundred.

The adult females laid their eggs in groups of ten on the abaxial surface of the leaves of $P$. chinense. Usually the early larvae feed on the outer tissues of the leaf where the adult female oviposited but when they have developed bigger, they feed on most of the leaf tissues. 
The adult weevils feed mostly on leaves and soft stem tissues of $P$. chinense. The adults feed randomly but the larvae produced local spot symptom. Both larvae and adults caused defoliation of $P$. chinense.

Starvation test of both larvae and weevils of Haltica sp. against 14 crop species and 33 weed species showed that the insects feed on six of the test weeds: $P$. chinense, $P$. barbatum, $P$. nepalense, $P$. longisetum, Ludwigia octovalvis and L. parennis. $P$. chinense was the most preferred by the larvae. The rank of preference of the larvae is presented in Appendix 2. It seemed that the insect is polygophagous but feeds especially on Polygonum spp.

It is strongly suspected that $P$. chinense, $P$. barbatum, $P$. nepalense and $P$. longisetum contain the key feeding stimulant for Haltica sp.

Biological control using insects has a risk of changing from control agent to pest of crop plants in the future. Luckily in Indonesia, there is no known crop plant belonging to Polygonum sp. and Ludwigia sp. There are some closely related insects to Haltica sp. namely $H$. caerulea Oliv, $H$. cyanea (Weber) and $H$. caerulea which were reported as promising biological control agents of water primrose (Ludwigia spp.). A total of 123 plant species have been tested by CIBC (Sankaran et al. 1967 cited by Mangoendihardjo et al. 1977) which reported that these insects feed on Nicotiana tabacum under laboratory condition (Rao et al. 1977).

$H$. cyanea has also been reported to feed on leaves of some forest trees such as Ammonia baccifera, A. rotundifolia, Terminalia myriocarpa in India (Beeson 1941), and some food crops in Indonesia (Kalshoven 1981).

Haltica sp. that was observed in this study was formerly suspected as $H$. caerulea but due to the supporting data on its host range, the authors of this paper name it Haltica sp. for the moment. The correct name of the insect will be confirmed later.

Preliminary damage potential test using weevils on $P$. chinense grown in plastic pots indicated that the insect produced serious damage on the weed. Populations of 1, 2 and 3 pairs of adult weevil caused a reduction on the fresh weight increment of 46.19, 74.33 and $75.53 \%$, respectively within the last 10 days of the 30 -day experiment.

\section{CONCLUSION AND RECOMMENDATIONS}

\section{Conclusion}

Haltica sp. (Coleoptera: Halticidae) is a promising candidate as biological control agent of Polygonum chinense. 
The role of Haltica sp. as biological control agent-Kasno, S. Tjitrosemito \& Sunjaya

\section{Recommendations}

1. Further studies are needed especially on its host range before deciding to recommend it as a biological control agent of $P$. chinense.

2. Confirmation of the correct identification of the insect is necessary.

\section{REFERENCES}

BACKER, C.A. and D.F.V. SLOOTEN. Geillustreerd handboek der Javaansche theeonkruiden en hunne beteekenis voor de cultuur. Drukkerijen Ruygrok \& Co. Jakarta.

BEESON, C.F.C. 1941. The ecology and control of the forest insects of India and the neighbouring countries. Dept. of Agriculture. Dehra Dun.

HARADA,J., Y. PAISOOKSANTIVATANAand S. ZUNGSONTIPORN. 1987. Weeds in the highlands of Northem Thailand. Project Manual No. 3 Nat. Weed Science Res. Inst. Project. Bangkok.

KALSHOVEN, L.G. 1981. The pests of crops in Indonesia. Revised edition by P.A. Van der Laan. PT Ichtiar Baru Van Hoeve. Jakarta.

MANGOENDIHARDJO, S., O. SETYAWATI, R.A. SYED and S. SOSROMARSONO. 1977. Insects and fungi associated with some aquatic weeds in Indonesia. Proc. Sixth Asian Pacific Weed Science Society Conference. Jakarta.

RAO, V.P., M. A. GANI and T. SANKARAN. 1971. A review of the biological control of insects and other pests in South East Asia and the Pacific Regions. Techn. Communication No. 6. CIBC, Trinidad. 
Appendix 1. Response of the larvae and adults of Ha/tica sp. on several test plants during starvation test

No. Plant species

Response

\section{AMARANTHACEAE}

1. Amaranthus spinosus $L$. ASTERACEAE

2. Ageratum conyzoides L.

3. Bidens pilosa $\mathrm{L}$.

4. Crassocephalum crepidioides (Benth.) S. Moore

5. Chromolaena odorata (L.) R.M. King \& H. Robinson

6. Eupatorium riparium $\mathrm{Reg}$.

7. Eleutheranthera ruderalis Poit.

8. Mikania micrantha H.B.K.

9. Tridax procumbens $\mathrm{L}$.

\section{BALSAMINACEAE}

10. Impatiens platypetala Lindl.

\section{CARPARACEAE}

11. Cleome rutidosperma $\mathrm{DC}$

\section{CRUCIFERACEAE}

12. Nasturtium heterophyllum BL.

\section{CYPERACEAE}

13. Cyperus rotundus UPHORBIACEAE

14. Phyllanthus niruri $\mathrm{L}$.

\section{GRAMINEAE}

15. Imperata cylindrica (L.) Raeuschel

16. Paspalum conjugatum Berg.

17. Sporobulus berteroanus Trin. MELASTOMATACEAE

18. Oxalis barrelieri $\mathrm{L}$.

19. Oxalis corniculata L.

\section{ONAGRACEAE}

20. Ludwigia octovalvis (Jacq.) Raven

21. Ludwigia perennis $\mathrm{L}$.

22. Ludwigia peruviana (L.)

\section{POLYGONACEAE}

23. Polygonum barbatum $\mathrm{L}$.

24. Polygonum chinense L.

25. Polygonum longisetum $\mathrm{De} \mathrm{Br}$.

26. Polygonum nepalense Meissn.

$$
\begin{gathered}
+ \\
++++ \\
++ \\
+++
\end{gathered}
$$


Appendix 1. (Continued).

\begin{tabular}{ccc}
\hline \hline No. & Plant species & Response \\
\hline RUBIACEAE &
\end{tabular}

27. Borreria data (Aubl) DC

28. Borreria laevis Griseb.

29. Diodia sarmentosa Swartz.

VERBENACEAE

30. Lantana camara L.

31. Stachytarpheta indica (L.) CROP SPECIES AMARYLLIDACEAE

1. A Ilium cepa $\mathrm{L}$.

2. Allium fistulosum $L$. ARACEAE

3. Colocasia esculenta (L.) BRASSICACEAE

4. Brassica oleraceae L. CONVOLVULACEAE

5. Ipomoea batatas Poir. GRAMINEAE

6. Oryza sativa L.

7. Zea mays L. LEGUMINOSAE

8. Arachys hypogea L.

9. Glycine $\max (\mathrm{L}$.

10. Phaseolus vulgaris L. MUSACEAE

11. Musa paradisiaca L. SOLANACEAE

12. Capsicum annuum $\mathrm{L}$.

13. Solarium lycopersicum L. THEACEAE

14. Cammelia sinensis (L.) O.K.

Note: - No feeding scars

+ Feeding scars present. 


\section{BIOTROPIA No. 4, 1990/1991}

Appendix 2. Response of larvae of Haltica sp. on several weed species during preferential test

\begin{tabular}{lc}
\hline \hline No. Weed species & Response \\
\hline 1. Polygonum chinense & ++++ \\
2. P. nepalense L. & +++ \\
3. P. longisetum De Br. & ++ \\
4. P. barbatum L. & + \\
5. Ludwigia octovalvis (Jacq.) Raven & + \\
6. L. perennis L. & + \\
\hline
\end{tabular}

